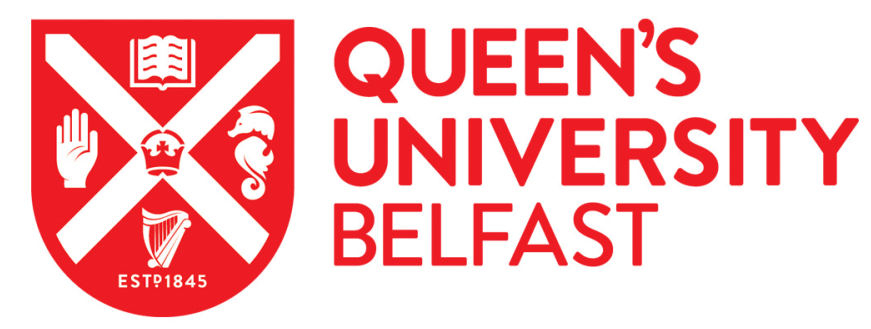

\title{
An Analysis of Liquidity Skewness for European Sovereign Bond Markets
}

Yan, W., Hamill, P., Li, Y., Vigne, S., \& Waterworth, J. (2018). An Analysis of Liquidity Skewness for European Sovereign Bond Markets. Finance Research Letters. https://doi.org/10.1016/j.frl.2018.02.027

\author{
Published in: \\ Finance Research Letters
}

\section{Document Version:}

Peer reviewed version

Queen's University Belfast - Research Portal:

Link to publication record in Queen's University Belfast Research Portal

\section{Publisher rights}

Copyright 2018 Elsevier.

This manuscript is distributed under a Creative Commons Attribution-NonCommercial-NoDerivs License

(https://creativecommons.org/licenses/by-nc-nd/4.0/), which permits distribution and reproduction for non-commercial purposes, provided the author and source are cited.

\section{General rights}

Copyright for the publications made accessible via the Queen's University Belfast Research Portal is retained by the author(s) and / or other copyright owners and it is a condition of accessing these publications that users recognise and abide by the legal requirements associated with these rights.

Take down policy

The Research Portal is Queen's institutional repository that provides access to Queen's research output. Every effort has been made to ensure that content in the Research Portal does not infringe any person's rights, or applicable UK laws. If you discover content in the Research Portal that you believe breaches copyright or violates any law, please contact openaccess@qub.ac.uk. 


\title{
An Analysis of Liquidity Skewness for European Sovereign Bond Markets
}

\author{
Wei Yan ${ }^{\mathrm{a}}$, Philip Hamill ${ }^{\mathrm{b}}$, Youwei Li ${ }^{\mathrm{c}}$, Samuel A. Vigne ${ }^{\mathrm{c}}$, James Waterworth ${ }^{\mathrm{c}}$

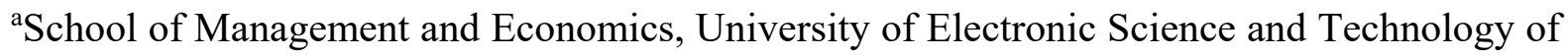 \\ China, Chengdu, 611731, China \\ ${ }^{\mathrm{b}}$ Emirates Institute for Banking and Financial Studies, Dubai, UAE \\ 'Queen's Management School, Queen's University Belfast, United Kingdom
}

\begin{tabular}{ll} 
ARTICLE INFO & ABSTRACT \\
\cline { 1 - 1 } Article history: & $\begin{array}{l}\text { We examine liquidity skewness by providing an analysis of bid- } \\
\text { ask spreads for a comprehensive high-frequency dataset } \\
\text { comprising Eurozone countries' sovereign bonds. European } \\
\text { sovereign bond markets exhibited increasing positive skewness } \\
\text { over the sample period which was most extreme for Greece, }\end{array}$ \\
JEL classification: & $\begin{array}{l}\text { Ireland and Portugal. We argue that positive skewness reflects } \\
\text { decreased liquidity during volatile periods. We also report } \\
\text { G01 }\end{array}$ \\
G23 & $\begin{array}{l}\text { negative skewness in 2007. This can be explained by a feature } \\
\text { of the limit-order book rubric of the MTS market where market- }\end{array}$ \\
m24 & $\begin{array}{l}\text { me current best-price to reduce unwanted inventory without } \\
\text { having to execute a market-order. }\end{array}$ \\
Keywords: &
\end{tabular}




\section{Introduction}

This paper contributes to the sparse literature examining trends in the inter-temporal behavior of liquidity, and liquidity skewness, in financial markets. Specifically, it provides an analysis of liquidity and its skewness of the bid-ask spread for high-frequency data from the Mercato dei Titoli di Stato (MTS) inter-dealer fixed-income securities platform from July 2005 to December 2011. The analysis encompasses seven key eurozone countries including Germany, France, Greece, Spain, Ireland, Italy, Portugal and Spain. Empirically and theoretically many studies have addressed equity market liquidity (Hameed et al., 2010; Garleanu and Pedersen, 2011; Degryse, 1997; Booth et al., 1999; Boehmer, 2005, Swan and Westerholm, 2004; Aitken et al., 2006). However, only a few studies specifically investigate liquidity skewness. Roll and Subrahmanyam (2010) report that bid-ask spreads for US equities have declined, on average, and have become increasingly positively skewed. A finding which was consistent across exchanges as well as size, price and volume quartiles. They attribute the emergence of positive skewness to increased competition among market makers over time. Hsieh, et al. (2018) also report that over the period 1996 to 2009 UK equities' average bid-ask spreads declined and was accompanied by increasing positive skewness. They also rely on increased competition among market-makers to explain their findings. The aim of this paper is to add to this literature by examining liquidity skewness for sovereign bond markets over an important period encompassing the global financial crisis and the European sovereign debt crisis.

In the context of the eurozone, Cheung, de Jong and Rindi (2005) examine every transaction for Italian, French, German and Belgian sovereign bonds traded on the MTS platform from January 2001 until May 2002. They find that liquidity indicators such as bid-ask spread and effective spread are related to the maturity of the instruments. Dunne et al. (2007) study the determinants of execution costs and the role of transparency in the European government bond market for select months during 2003 to 2005. They find that execution quality is related to issuer size, technique and imposed obligations. Darbha and Dufour (2013) analyse liquidity on MTS before and during the crisis using data from January 2004 to July 2010. They report that liquidity did not provide a significant incremental explanatory contribution to time-series dynamics of yields before the crisis, but did become significant during the crisis. Further, they find that liquidity played an important role in explaining yield spreads both before and during the crisis. Petrella and Resti (2016) perform an empirical analysis of eurozone government bonds over the period 2005 to 2012. They find that characteristics such as duration, rating, and issue size affect liquidity, and that these variables help identify resilient bonds under stressed conditions. More recently, Pelizzon, Subrahmanyam, Tomio and Uno (2016) investigate the relation between credit risk and liquidity for the Italian sovereign bond market during the Eurozone crisis and the impact of subsequent European Central Bank (ECB) interventions. They report that credit risk influences the liquidity of the market with this relationship exhibiting a threshold effect, becoming stronger, when the CDS spread exceeds 500 basis points (bp). And that ECB Long-Term Refinancing Operations (LTRO) interventions lead to a structural break which significantly diminished the intensity of credit-risk liquidity relationship from the onset of 2012.

We conduct the analysis on the whole yield curve for each of the seven countries and report two main findings. First, similar to equity markets, bond markets exhibited increasing positive skewness over the sample period which was most extreme for Greece, Ireland and Portugal. In contrast to the explanation of increased competition for equity markets, we argue that positive 
bond market skewness result reflects decreased liquidity during volatile periods. Second, we report a period of negative skewness in 2007. This can be explained by a feature of the limitorder book structure of the MTS market where market makers can submit limit-orders that are more competitive than the current best price to reduce unwanted inventory without having to execute a market-order and pay the bid-ask spread. By way of a simple stylized example we demonstrate how this result can emerge. The increase in skewness for the European sovereign debt market cannot be attributed to increased competition amongst market makers but rather a decrease in liquidity, specifically quoted depth, during volatile periods.

\section{Data and methodology}

The MTS data covers every transaction for French, German, Greek, Irish, Italian, Portuguese and Spanish government bonds being traded on the MTS platform from 1 July 2005 to 31 December 2011. For each instrument included in the study the limit-order book is available in aggregate format with millisecond timestamp. The direction of the trade - buy or sell - is also specified. We perform the analysis on all available instruments that were quoted on both MTS Domestic Markets and EuroMTS for the entire sample period, using snap-shot observations every 15 minutes from 09:00 to 16:30. Table 1 provides a breakdown of the sample.

\section{INSERT TABLE 1 ABOUT HERE}

For Germany there were 9 bonds available for the entire period, Spain 7, France 12, Greece 5, Ireland 3, Italy 10 and for Portugal there were 4. For each bond there are 49,500 observations, which, when multiplied by the number of bonds per country, results in a total number of observations for the study of 2,475,000. Similar to Antonakakis and Vergos (2013) we categorise the countries into core and periphery, but also add a third category semi-core comprising Italy and Spain in our analysis. Our analysis is conducted over three distinct subperiods encompassing a period of pre-crisis calm, the global financial crisis and the European sovereign debt crisis. We have:

- $\quad$ Pre-Crisis Period (PRE): $1^{\text {st }}$ July 2005 to $31^{\text {st }}$ May 2007.

- Global Financial Crisis (GFC): $1^{\text {st }}$ June 2007 to $31^{\text {st }}$ December 2008.

UK stopped lending to each other in July 2007 due to market fears that counterparts were exposed to the emerging US sub-prime crisis. Also, in July, Bear Sterns informed investors that they would get little, if any, money back from two hedge funds with large holdings of sub-prime mortgages. LIBOR rates spike. Following a BBC report on the $13^{\text {th }}$ September, Northern Rock experienced a bank-run on the $14^{\text {th }}$. It was subsequently nationalised on $22^{\text {nd }}$ February 2008.

- European Sovereign Debt Crisis (ESDC): $1^{\text {st }}$ January 2009 to $31^{\text {st }}$ December 2011.

On $15^{\text {th }}$ January 2009, the Irish government announced that it would nationalize Anglo Irish Bank. Fall 2009 Greece's budget was revised highlighting that the deficit for that year would be significantly higher than previously predicted. On May 2nd, 2010 the EU endorsed the IMF announce an $€ 85 \mathrm{bn}$ first European financial rescue plan for Greece. Problems persisted and Greece and a second rescue package was negotiated with Greece in 2011. On $28^{\text {th }}$ November 2010 the Trokia (European Commission, European Central Bank and International Monetary Fund agreed an €85bn bailout deal with the Irish 
Government. On $5^{\text {th }}$ May 2011 Portugal agrees with the EU and IMF on a $€ 78$ bn bailout in exchange for an austerity programme.

The bid-ask spread is a measure of market quality, defined as the difference between the best bid price and best ask price. It gives the difference in price at which the market makers are willing to buy and sell the asset. Within each maturity bucket we compare the values over the entire period to see how they changed over time. We use snap-shot observations where available, every 15 minutes from 09:00 to 16:30. Formally, we define bid-ask spread as follows:

$$
\text { Bid-ask spread } \quad \frac{1}{T} \sum_{t=1}^{T}\left(\left(A_{1}\right)_{t}-\left(B_{1}\right)_{t}\right)
$$

where $A_{1}$ is the best ask price and $B_{1}$ is the best bid price.

There are a few caveats to be taken into consideration when using the daily bid-ask spread as a measure of liquidity. It is sensitive to outliers, especially when liquidity is low, and there are not enough quotes on the market to disguise wide spreads. In this section, we give an overview of the metrics used in the quote skewness analysis. The analysis is built around the quoted bidask spread, as defined in equation (1). we examine the mean, standard deviation and skewness, defined as follows:

$$
\begin{array}{ll}
\text { Mean } & \frac{1}{n} \sum x_{i} \\
\text { Standard deviation } & \sqrt{\frac{\sum(x-\bar{x})^{2}}{(n-1)}} \\
\text { Skewness } & \frac{n}{(n-1)(n-2)} \sum\left(\frac{x_{j}-\bar{x}}{s}\right)^{3}
\end{array}
$$

where $x$ is the quoted bid-ask spread. The mean is the standard arithmetic mean, the standard deviation is a measure used to quantify the variation or dispersion of the values, and the skewness characterises the degree of asymmetry around the mean. Calculations were performed on each bond using snap-shot observations every 15 minutes from 09:00 to 16:30 and aggregate at different frequencies as required, detailed in the results section.

\section{Empirical results}

\subsection{Liquidity skewness}

Table 2 panel A reports the descriptive statistics for quoted bid-ask spreads, averaged by subperiods: calm pre-crisis period, global financial crisis (GFC) and European sovereign debt crisis (ESDC), with panel B reporting the same analysis by category: core, semi-core and periphery. Figure 1 depicts quarterly quoted mean bid-ask spreads (Panel A) and skewness (Panel B) by country. The bid-ask spread increased in all periods for all countries from the pre-crisis period to the GFC, and from the GFC to the ESDC reflecting the decrease in liquidity and increase in trading due to successive crises. For example, Germany's mean bid-ask spread of 0.050 in the pre-crisis calm period increased to 0.157 during the GFC which again increased to 0.182 during the ESDC. This pattern is repeated for the remaining six countries in panel A. As would be 
expected Greece, Ireland and Portugal experienced the largest increases in mean bid-ask spread during the sovereign debt crisis period with spreads of $2.973,1.851$ and 2.081 respectively.

\section{INSERT TABLE 2 ABOUT HERE}

Bid-ask spread skewness was negative - left-skew - for Germany, Italy, Ireland and Portugal over the pre-crisis period and positive for Spain and Greece. Again, we see a similar pattern to changes in mean spreads with some variation. Germany's skewness went from -2.986, to 2.997 but then decreased to 1,670 during the final sovereign debt crisis period. France, Italy, Spain and Portugal experienced increases in skewness over each sub period, while Ireland's and Greece's skewness peaked during the GFC at 1.955 and 3.075 respectively. Figure 1 helps visualise these findings over time and pin-point specific periods of interest. It is evident that bid-ask spreads began to increase during 2007 and accelerated as the GFC and ESDC deepened, with Greece experiencing a spike between Q1 and Q3 2010. It is evident from panel A that Greece, Ireland and Portugal were by the end of the sample period experiencing significantly high bid-ask spreads relative to the core and semi-core countries.

\section{INSERT FIGURES 1 AND 2 ABOUT HERE}

Panel B allows us to pinpoint negative spikes in skewness at Q1 2007 which by Q3 2007 is mostly positive above the zero line. Overall, skewness was similar across all seven countries for the whole period. Initially it was very low, and negative for Germany, Italy, Ireland and Portugal, and rose for all countries in 2007 around the first signs of trouble in the financial markets; slightly earlier for Greece reflecting the position of increased risk. It decreased marginally in 2008 before rising in 2009 and decreasing again through 2010 into 2011. Skewness was at a maximum at the beginning of each crisis. A less volatile picture emerges in figure 2 confirming this pattern when we plot the same analysis by category: core, semi-core and periphery. These figures further highlight the divergence of the mean bid-ask spread across the core, semi-core and periphery compared to the similarity of the skewness dynamics. This plot shows more clearly that skewness peaked at the beginning of each crisis. To explain our empirical findings of negative and increasing inter-temporal skewness we provide two simple stylised examples.

\subsection{Stylised example}

Negative skewness can be explained by a feature of the limit-order book structure of the MTS market. In addition to providing firm two-way quotes market makers can submit limit-orders. Price takers can only trade by submitting market-orders. Due to market-making activity marketmakers may obtain unwanted inventory positions that they need to unwind. In calm market conditions, when there is low market risk, a market maker can enter a limit-order that is more competitive than the current best price with the aim of having it aggressed by a price-taker. In this way the market maker would flatten the unwanted inventory position without having to execute a market-order and pay the bid-ask spread. Table 4 exemplifies how this situation might develop and the impact it has on bid-ask spread skewness. 


\section{INSERT TABLES 3 ABOUT HERE}

The 'Bid', 'Ask' and 'Spread' columns represent the bid quote price, ask quote price and bidask spread from the top of the limit order book. There are six periods representing calm trading. Scenario 1 is the control scenario and details a calm market with no quote updates or limit orders affecting the top of the book. Scenario 2 is the same in all respects, except in period 4 where the market maker places a limit-order on the bid side in an attempt flatten a short position and avoid paying the full bid-ask spread. Consequently, negative skewness emerges. In our simple stylised example skewness decreases from zero in scenario 1 to -2.449 in scenario 2 .

Roll and Subrahmanyam (2010) conclude that increased competition between market makers, and the subsequent reduction of cross-subsidisation across periods of high and low asymmetric information, led to larger bid-ask spreads during periods where private information was more material and, in turn, an increasing right-skewness in periods of high asymmetric information. This argument is based on Glosten and Milgrom (1985) who show that in markets where market makers do not have monopoly power they compensate for periods of high asymmetric information by increasing the bid-ask spread. The increase in bid-ask spread skewness for the European sovereign debt market cannot be attributed to increased competition amongst market makers but rather to a decrease in liquidity. Specifically quoted depth during turbulent market periods. The average skewness increased over the sample, with spikes appearing at discrete points throughout the sample.

\section{INSERT TABLE 4 ABOUT HERE}

Table 4 provides another stylised example of how increased skewness can develop when a subset of market makers withdraw from the market ${ }^{1}$. Scenario 1 is the control scenario where there are three active market-makers. In period 5 market maker A acquires an unwanted long position and so in period 6 significantly decreases his bid price in an attempt to avoid buying more. Their obligations require them to quote so they cannot completely withdraw from the market. Due to the presence of market-makers B and C this widening of the bid-ask spread by market-maker A does not affect the top of the book. Scenario 2 is the same in all respects for market-maker A. This time however market- makers B and C are assumed to have withdrawn from the market. In this case, the lack of quoted depth has a direct effect on the top of the book and, accordingly, increases the bid-ask spread skewness which increases from zero in scenario 1 to 2.449 in scenario 2 .

${ }^{1}$ Pelizzon et al. (2016) show that under conditions of stress a fraction of market-makers withdraw from the market. 


\section{Conclusion}

In their seminal paper Roll and Subrahmanyam (2010) report that bid-ask spreads for US equities have declined, while at the same time becoming increasingly right-skewed. An outcome which is consistent with increased competition amongst market makers. Hsieh et al. (2018) confirm these findings for UK listed equities. This study extends the sparse literature examining liquidity skewness to seven eurozone sovereign debt markets from June 2005 to December 2011. Our results show an increase in quoted bid-ask spreads for the benchmark government bonds for seven representative eurozone countries which was accompanied by an increase in right (positive) skewness. Also, while there was significant bid-ask spread heterogeneity across country, skewness was largely consistent across all countries and reached a maximum at the beginning of both the global financial and European sovereign debt crises.

We add to the literature by providing an explanation for the increase in skewness in times of crisis for the inter-dealer sovereign bond markets in Europe. In contrast to the competition amongst market-makers explanation reflecting inter-temporal innovations in equity markets, we contend that during crisis periods liquidity is the major factor in bond markets and the lack of quoted depth has a direct effect on the top of the book and, accordingly, increases the bidask spread skewness. We also report a period of negative skewness for Germany, Italy, Ireland and Portugal in 2007 over a relatively calm pre-crisis market period. This can be explained by a feature of the limit-order book rubric of the MTS market where market-makers can submit limit-orders that are more competitive than the current best price to reduce unwanted inventory without having to execute a market-order and pay the bid-ask spread. 


\section{References}

Antonakakis, N., and Vergos, K., 2013. Sovereign bond yield spillovers in the euro zone during the financial and debt crisis. Journal of International Financial Markets, Institutions and Money 26, 258-272.

Aitken, M. J., Cook, R.M., deB. Harris, F. H., and McInish, T.H., 2006. Market design and execution cost for matched securities across seven tier-one markets. Mimeo.

Boehmer, E., 2005. Dimentions of execution quality: Recent evidence for US equity markets. Journal of Financial Economics, 78(3), 553-582.

Booth, G.G., Iversen, P., Sakar, S.K., Schmidt, H., and Young, A., 1999. Market structure and bid-ask spreads: IBIS vs NASDAQ. European Journal of Finance 5, 51- 71.

Cheung, Y., de Jong, F., and Rindi, B., 2005. Trading European sovereign bonds: the microstructure of the MTS trading platforms. European Central Bank Working Paper Series 432.

Darbha, M. and Dufour, A. (2013) Microstructure of the Euro-area government bond market. In: Baker, H. K. and Kiymaz, H. (eds.) Market microstructure in emerging and developed markets. Robert W. Kolb series in finance. John Wiley, Hoboken, pp. 39-58

Degryse, H., 1997. The total cost of trading Belgian shares: Brussels versus London. CEPR Discussion Paper 1581.

Dunne, P.G., Moore, M.J., and Portes, R., 2007. Benchmark status in fixed-income asset markets. Journal of Business Finance and Accounting 34, 1615-1634.

Garleanu, N.B., and Pedersen, L.H., 2011. Margin-based asset pricing and deviations from the law of one price. Review of Financial Studies 24(6), 1980-2022.

Glosten, L. R., \& Milgrom, P. R. (1985). Bid, ask and transaction prices in a specialist market with heterogeneously informed traders. Journal of Financial Economics, 14(1), 71-100.

Hameed, A., Kang, W., and Viswanathan, S., 2010. Stock market declines and liquidity. Journal of Finance 65(1), 257-293.

Hsieh, T-H., Li. Y., McKillop, D. G. and Wu. Y., 2018. Liquidity Skewness in the London Stock Exchange, International Review of Financial Analysis, 56, 12-18.

Pelizzon, L., Subrahmanyam, M. G., Tomio, D., and Uno, J., 2016. Sovereign Credit Risk, Liquidity, and ECB Intervention: Deux ex Machina?, Journal of Financial Economics, Vol. 122 (1), pp. $86-115$

Petrella, Giovanni and Resti, Andrea, An Empirical Analysis of Eurozone Government Bonds Liquidity: Determinants, Predictability and Implications for the New Bank Prudential Rules (December 18, 2016). BAFFI CAREFIN Centre Research Paper No. 2016-45. Available: SSRN: https://ssrn.com/abstract $=2888396$

Roll, R., and Subrahmanyam, A., 2010. Liquidity skewness. Journal of Banking and Finance 34, 25622571.

Swan, P.L., and Westerholm, J., 2004. Transparency generally beats opacity: how transparency choice impacts global equity market performance. Working Paper, University of New South Wales School of Banking and Finance. 
Table 1: Sample

\begin{tabular}{llccc}
\hline Country & Classification & $\begin{array}{c}\text { Number of } \\
\text { bonds }\end{array}$ & $\begin{array}{c}\text { Observations Per } \\
\text { Bond }\end{array}$ & $\begin{array}{c}\text { Observations Per } \\
\text { Country }\end{array}$ \\
\hline Germany & Core & 9 & 49,500 & 445,500 \\
France & Core & 12 & 49,500 & 594,000 \\
Spain & Semi-core & 7 & 49,500 & 346,500 \\
Italy & Semi-core & 10 & 49,500 & 495,000 \\
Ireland & Periphery & 3 & 49,500 & 148,500 \\
Greece & Periphery & 5 & 49,500 & 247,000 \\
Portugal & Periphery & 4 & 49,500 & 198,000 \\
\hline & & \multicolumn{2}{c}{ Total } & $2,475,500$ \\
\hline
\end{tabular}


Table 2 Quoted bid-ask spread statistics

Panel A: Quoted bid-ask spread statistics, by country

\begin{tabular}{lllllllll}
\hline \multirow{2}{*}{ Calm } & & Ger & Fra & Ita & Spa & Gre & Ire & Por \\
\cline { 3 - 8 } & Mean & 0.050 & 0.071 & 0.047 & 0.063 & 0.072 & 0.049 & 0.043 \\
& Std. dev & 0.007 & 0.008 & 0.005 & 0.006 & 0.008 & 0.008 & 0.004 \\
& Skew & -2.986 & -0.150 & -0.219 & 0.499 & 1.531 & -0.553 & -1.881 \\
Glob. fin. crisis & & & & & & & & \\
& Mean & 0.157 & 0.298 & 0.190 & 0.320 & 0.493 & 0.401 & 0.257 \\
& Std. dev & 0.155 & 0.286 & 0.183 & 0.315 & 0.708 & 0.533 & 0.319 \\
& Skew & 2.997 & 1.679 & 1.841 & 1.560 & 3.075 & 1.955 & 1.180 \\
& & & & & & & & \\
& Mean & 0.182 & 0.318 & 0.410 & 0.604 & 2.973 & 1.851 & 2.081 \\
& Std. dev & 0.069 & 0.193 & 0.336 & 0.457 & 2.964 & 1.623 & 2.466 \\
& Skew & 1.670 & 1.717 & 2.884 & 1.972 & 2.078 & 1.339 & 1.727
\end{tabular}

Panel B: Quoted bid-ask spread statistics, by core, semi-core and periphery

Core Semi-core Periphery

$\begin{array}{lllll}\text { Calm } & \text { Mean } & 0.060 & 0.055 & 0.055 \\ & \text { Std. dev } & 0.008 & 0.005 & 0.007 \\ & \text { Skew } & -1.568 & 0.140 & -0.301 \\ & & & & \\ \text { Glob. fin. crisis } & \text { Mean } & 0.228 & 0.255 & 0.384 \\ & \text { Std. dev } & 0.220 & 0.249 & 0.520 \\ & \text { Skew } & 2.338 & 1.700 & 2.070 \\ & & & & \\ \text { Euro sov. debt crisis } & \text { Mean } & 0.250 & 0.507 & 2.302 \\ & \text { Std. dev } & 0.131 & 0.397 & 2.351 \\ & \text { Skew } & 1.694 & 2.428 & 1.715\end{array}$

Notes: The table displays summary statistics for the bid-ask spread calculated from the top of the book aggregated across both MTS Domestic Markets and EuroMTS. Snapshot observations are taken every 15 minutes from 0900-1630. The mean, standard deviation and skewness statistics are first calculated for each bond over the period, then equally weighted averages of the resulting individual bond statistics are computed by country. 
Figure 1

Panel A: Quarterly quoted bid-ask spread mean by country

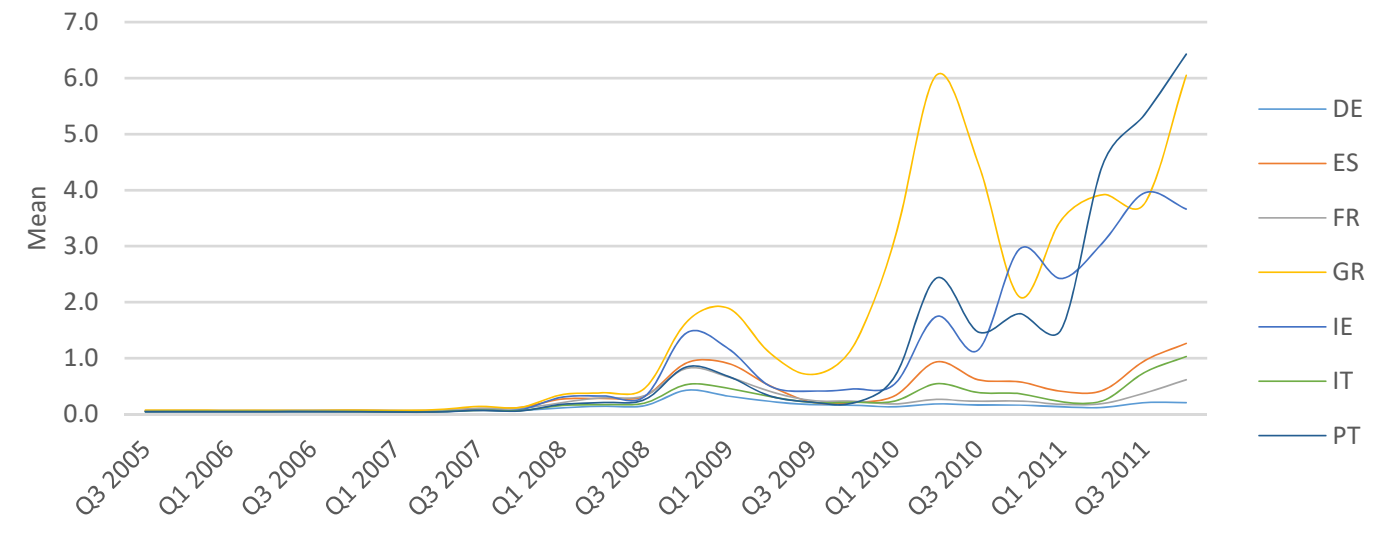

\section{Panel B: Quarterly quoted bid-ask spread skewness, by country}



Notes: These figures display the quarterly mean and skewness for the bid-ask spread by country calculated from the top of the book across both MTS Domestic Markets and EuroMTS. Germany (DE), Spain (ES), France (FR), Greece (GR), Ireland (IE), Italy (IT) and Portugal (PT). 
Figure 2

Panel A: Quarterly quoted bid-ask spread mean, by core, semi-core and periphery



Panel B: Quarterly quoted bid-ask spread skewness, by core, semi-core and periphery

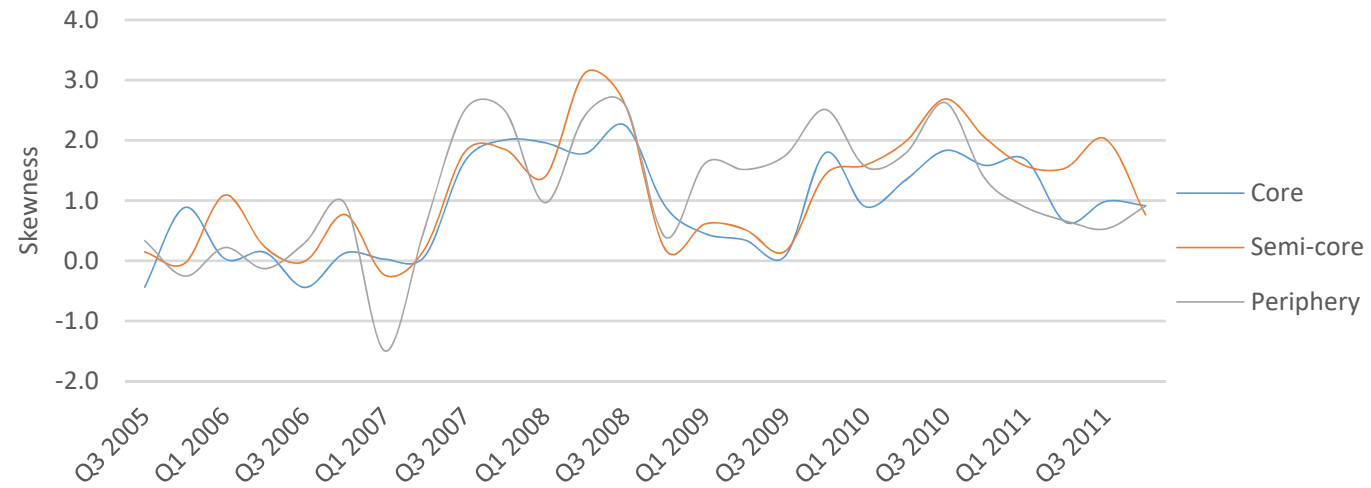

Notes: These figures display the quarterly mean and skewness for the bid-ask spread by core, semi-core and periphery calculated from the top of the book across both MTS Domestic Markets and EuroMTS. Germany (DE) and France (FR) $=$ Core; Spain (ES) and Italy (IT) = Semi-core; Greece (GR), Ireland (IE) and Portugal (PT) = Periphery. 
Table 3 Example leading to negative skewness

\begin{tabular}{lccccccc}
\hline & \multicolumn{3}{c}{ Scenario 1 } & & \multicolumn{3}{c}{ Scenario 2 } \\
\cline { 2 - 5 } \cline { 6 - 8 } & Bid & Ask & Spread & & Bid & Ask & Spread \\
\hline 1 & 99.915 & 100.015 & 0.100 & & 99.915 & 100.015 & 0.100 \\
2 & 99.915 & 100.015 & 0.100 & & 99.915 & 100.015 & 0.100 \\
3 & 99.915 & 100.015 & 0.100 & & 99.915 & 100.015 & 0.100 \\
4 & 99.915 & 100.015 & 0.100 & & 99.950 & 100.015 & 0.065 \\
5 & 99.915 & 100.015 & 0.100 & & 99.915 & 100.015 & 0.100 \\
6 & 99.915 & 100.015 & 0.100 & & 99.915 & 100.015 & 0.200 \\
& & & & & & \\
Mean & & & 0.100 & & & 0.094 \\
Skewness & & & 0.000 & & & -2.449 \\
\hline
\end{tabular}

Notes: This table shows an example of a change in bid-ask spread skewness in the same market across two scenarios. Scenario 1 is the control, and scenario 2 shows how a negative skewness can arise when a limit order is placed in an attempt to avoid paying the bid-ask spread (period 4). 
Table 4: Example leading to an increase in skewness

Panel A: Scenario 1, with the full complement of market makers

\begin{tabular}{|c|c|c|c|c|c|c|c|c|c|}
\hline & \multicolumn{2}{|c|}{ Market maker A } & \multicolumn{2}{|c|}{ Market maker B } & \multicolumn{2}{|c|}{ Market maker C } & \multicolumn{3}{|c|}{ Top of the book } \\
\hline & Bid & Ask & Bid & Ask & Bid & Ask & Bid & Ask & Spread \\
\hline 1 & 100.010 & 100.015 & 100.010 & 100.015 & 100.010 & 100.015 & 100.010 & 100.015 & 0.005 \\
\hline 2 & 100.010 & 100.015 & 100.010 & 100.015 & 100.010 & 100.015 & 100.010 & 100.015 & 0.005 \\
\hline 3 & 100.010 & 100.015 & 100.010 & 100.015 & 100.010 & 100.015 & 100.010 & 100.015 & 0.005 \\
\hline 4 & 100.010 & 100.015 & 100.010 & 100.015 & 100.010 & 100.015 & 100.010 & 100.015 & 0.005 \\
\hline 5 & 100.010 & 100.015 & 100.010 & 100.015 & 100.010 & 100.015 & 100.010 & 100.015 & 0.005 \\
\hline 6 & 98.000 & 100.015 & 100.010 & 100.015 & 100.010 & 100.015 & 100.010 & 100.015 & 0.005 \\
\hline Mean & & & & & & & & & 0.005 \\
\hline Skewness & & & & & & & & & 0.000 \\
\hline
\end{tabular}

Panel B: Scenario 2, with a subset of market makers withdrawn from the market

\begin{tabular}{|c|c|c|c|c|c|c|c|c|c|}
\hline & \multicolumn{9}{|c|}{ Market maker } \\
\hline & \multicolumn{2}{|c|}{ Market maker A } & \multicolumn{2}{|c|}{ Market maker B } & \multicolumn{2}{|c|}{$\mathbf{C}$} & \multicolumn{3}{|c|}{ Top of the book } \\
\hline & Bid & Ask & Bid & Ask & Bid & Ask & Bid & Ask & Spread \\
\hline 1 & 100.010 & 100.015 & - & - & - & - & 100.010 & 100.015 & 0.005 \\
\hline 2 & 100.010 & 100.015 & - & - & - & - & 100.010 & 100.015 & 0.005 \\
\hline 3 & 100.010 & 100.015 & - & - & - & - & 100.010 & 100.015 & 0.005 \\
\hline 4 & 100.010 & 100.015 & - & - & - & - & 100.010 & 100.015 & 0.005 \\
\hline 5 & 100.010 & 100.015 & - & - & - & - & 100.010 & 100.015 & 0.005 \\
\hline 6 & 98.000 & 100.015 & - & - & - & - & 98.000 & 100.015 & 2.015 \\
\hline Mean & & & & & & & & & 0.340 \\
\hline Skewness & & & & & & & & & 2.449 \\
\hline
\end{tabular}

Notes: This table shows an example of a change in bid-ask spread skewness in the same market across two scenarios. Scenario 1 is the control, and scenario 2 shows how a positive skewness can arise due to fewer market makers participating in the market. 